\title{
Experimental cross-infections by Perkinsus marinus and $P$. chesapeaki in three sympatric species of Chesapeake Bay oysters and clams
}

\author{
Christopher F. Dungan ${ }^{1, *}$, Kimberly S. Reece ${ }^{2}$, Rosalee M. Hamilton ${ }^{1}$, \\ Nancy A. Stokes ${ }^{2}$, Eugene M. Burreson ${ }^{2}$ \\ ${ }^{1}$ Maryland Department of Natural Resources, Cooperative Oxford Laboratory, 904 S. Morris St., Oxford, Maryland 21654, USA \\ ${ }^{2}$ College of William and Mary, Virginia Institute of Marine Science, PO Box 1346, Gloucester Point, Virginia 23062, USA
}

\begin{abstract}
In controlled laboratory transmission experiments, uniform doses of axenic in vitro isolate cultures of Perkinsus marinus from a Crassostrea virginica oyster, and of independent $P$. chesapeaki isolates from Chesapeake Bay Mya arenaria and Macoma balthica clams, were used to reciprocally challenge Perkinsus sp.-free $C$. virginica, $M$. arenaria, and $M$. balthica experimental hosts. Following mantle cavity inoculations, all 3 experimental hosts acquired high incidences (30 to $100 \%$ ) of infections by each of the 3 Perkinsus sp. isolates, based on PCR assays of DNAs from experimental host tissues that were collected through $60 \mathrm{~d}$ post-inoculation. Lesions containing proliferating pathogen cells were documented histologically in tissues of all experimental host species challenged with all isolates of both Perkinsus species. Experimental Perkinsus sp. challenge isolates were re-isolated and propagated in vitro from infected tissues of host molluscs from most (5 of 9) experimental treatment groups. Koch's postulates were generally satisfied to confirm experimental infections in all bivalve molluscs that were challenged with 3 isolates of 2 Perkinsus spp. These results suggest potential broad and overlapping host specificities for the 2 current Chesapeake Bay-endemic Perkinsus species: P. marinus and P. chesapeaki.
\end{abstract}

KEY WORDS: Dermo disease $\cdot$ Crassostrea virginica $\cdot$ Host-specificity $\cdot$ Macoma balthica $\cdot$ Mollusc $\cdot$ Mya arenaria Resale or republication not permitted without written consent of the publisher

\section{INTRODUCTION}

Based on results of then-novel Ray's fluid thioglycollate medium (RFTM) assays (Ray 1952), an early survey of Chesapeake Bay molluscs reported that diverse non-oyster hosts are infected by Perkinsus marinus (= Dermocystidium marinum) (Andrews 1953). At that time, $P$. marinus had recently been described as a lethal pathogen of Gulf of Mexico oysters (Mackin et al. 1950), and had also been detected in the earliest (1949) Chesapeake Bay oyster samples examined for that parasite (Ray \& Chandler 1955, Andrews \& Hewatt 1957). A distinctive Perkinsus sp. parasite was subsequently reported to infect Chesapeake Bay Macoma balthica clams (Valiulis \& Mackin 1969), and a parasite from that clam host was recently described as $P$. andrewsi (Coss et al. 2001). Perkinsus sp. infections were also reported as prevalent among Mya arenaria (McLaughlin \& Faisal 2000) and Tagelus plebeius (Dungan et al. 2002) commercial clams in mesohaline Chesapeake Bay waters, and a parasite of the former host was described as P. chesapeaki (McLaughlin et al. 2000). The $P$. chesapeaki description was subsequently emended to include parasites infecting both $T$. plebeius and $M$. balthica clams, and $P$. andrewsi was recognized as a junior synonym of $P$. chesapeaki (Burreson et al. 2005).

Histological and RFTM assays in current and historic use for diagnoses of Perkinsus spp. infections in mollusc hosts do not differentiate $P$. marinus and $P$. chesapeaki. Thus, species identities of parasites detected by such generic assays are uncertain in light of the several 
Perkinsus spp. now known to infect sympatric Chesapeake Bay bivalve molluscs. However, species-specific polymerase chain reaction (PCR) assays now allow sensitive detection and discrimination of Perkinsus species whose DNAs may be present in tissue samples (Coss et al. 2001, Burreson et al. 2005, Moss et al. 2006) or environmental samples (Audemard et al. 2004).

With the recent synonymy of Perkinsus chesapeaki and $P$. andrewsi, only $P$. marinus and $P$. chesapeaki are now recognized to co-occur in Chesapeake Bay waters (Burreson et al. 2005). Based on PCR results, both of these Perkinsus spp. are inferred to cross- or co-infect several sympatric Chesapeake Bay bivalve molluscs (Kotob et al. 1999, Coss et al. 2001). With a single apparent exception (McLaughlin \& Faisal 1998), however, in vitro Perkinsus sp. isolates propagated from several Chesapeake Bay clam species have uniformly proven to be $P$. chesapeaki, while numerous in vitro isolates from Chesapeake Bay oysters have uniformly been identified only as $P$. marinus (La Peyre et al. 2006). Results from species-specific in situ assays to confirm PCR-inferred co-infections by multiple Perkinsus species are lacking, as are experimental results that confirm or refute the broad host specificities inferred for the 2 Perkinsus spp. that are currently endemic in Chesapeake Bay.

To empirically resolve the possible host specificities of Perkinsus marinus and P. chesapeaki, we report results of controlled laboratory experiments in which 3 in vitro isolate cultures of $P$. marinus and $P$. chesapeaki $(=P$. andrewsi $)$ were used to reciprocally challenge Perkinsus sp.-free oysters and clams that are sympatric source-hosts for these parasite species in Chesapeake Bay waters.

\section{MATERIALS AND METHODS}

Experimental molluscs. Perkinsus sp. parasites are not reported in USA Pacific coast molluscs, which include conspecifics of several Perkinsus sp.-infected Chesapeake Bay mollusc hosts. Wild, Perkinsus sp.free Mya arenaria (16 to $70 \mathrm{~mm}$ shell length) and Macoma balthica (9 to $25 \mathrm{~mm}$ shell length) clams were collected from the Yaquina Bay estuary near Newport, Oregon. Perkinsus sp.-free Crassostrea virginica oysters (31 to $52 \mathrm{~mm}$ shell height) that were propagated from descendents of broodstocks imported during the early 1900s to British Columbia, Canada, were acquired from Taylor Shellfish (Shelton) facilities in southern Puget Sound. Clams and oysters were shipped to Oxford, Maryland, under humidified refrigeration, and maintained upon arrival at 20 to $23^{\circ} \mathrm{C}$ in separate, covered aquaria containing 25 ppt artificial seawater (ASW).
Pathogen isolate cultures. Three in vitro isolates of 2 Perkinsus species from Chesapeake Bay bivalve molluscs were obtained from the American Type Culture Collection (ATCC, Manassas, VA) for use as challenge experiment inocula. These included $P$. marinus isolate ATCC 50439 from a Crassostrea virginica oyster (Dungan \& Hamilton 1995), P. chesapeaki neohapantotype isolate ATCC PRA-65 from a Mya arenaria clam (Burreson et al. 2005), and $P$. chesapeaki (= P. andrewsi holotype) isolate ATCC 50807 from a Macoma balthica clam (Coss et al. 2001). Isolate suspension cultures were propagated at $27^{\circ} \mathrm{C}$ in $850 \mathrm{mOsm} \mathrm{kg}{ }^{-1}(29 \mathrm{ppt})$ Dulbecco's modified Eagle's (DME):Ham's F-12 Perkinsus sp. culture medium (Burreson et al. 2005) that was supplemented to the following final concentrations with fetal bovine serum (FBS, $3 \% \mathrm{v} / \mathrm{v}$ ), HEPES buffer $(25 \mathrm{mM})$, sodium bicarbonate $(7 \mathrm{mM})$, yeast extract ultrafiltrate (Sigma Y4375, 0.2 \% v/v), lipid mixture (Sigma L5146, $0.1 \% \mathrm{v} / \mathrm{v})$, glucose $(0.05 \% \mathrm{w} / \mathrm{v})$, trehalose $(0.01 \% \mathrm{w} / \mathrm{v})$, galactose $(0.01 \% \mathrm{w} / \mathrm{v})$, L-glutamine $(2 \mathrm{mM})$, penicillin $\left(100 \mathrm{U} \mathrm{ml}^{-1}\right)$, and streptomycin $\left(100 \mu \mathrm{g} \mathrm{m}^{-1}\right)$ (DME/F12-3).

Experimental inocula. Perkinsus spp. cultures were expanded in vitro to the desired inoculum cell numbers by continuous, exponential propagation in ventilated T75 tissue culture flasks. Experimental inoculum cells from isolate cultures were harvested separately on 3 successive days, when replicate cell suspensions were pooled, and cells were pelleted by centrifugation at $300 \times \mathrm{g}$. Cell pellets were re-suspended in $10 \mathrm{ml}$ of 25 ppt sterile artificial seawater (SASW) for counting. Viable pathogen cell concentrations were estimated by hemacytometer counts of neutral red-stained suspension aliquots, and $1 \times 10^{8}$ viable pathogen cells were transferred into $50 \mathrm{ml}$ of SASW for overnight, stationary-phase holding $\left(2 \times 10^{6}\right.$ cells $\left.\mathrm{ml}^{-1}\right)$ at $20^{\circ} \mathrm{C}$.

For inoculum suspension preparation on the following morning, cells from $10 \mathrm{ml}$ of quantified pathogen cell suspensions in SASW were concentrated by centrifugation for $5 \mathrm{~min}$ at $300 \times g$, and cell pellets were resuspended in $1 \mathrm{ml}$ of SASW as experimental inocula. Inoculum suspensions were loaded into $1 \mathrm{ml}$ insulin syringes for delivery of standard $50 \mu \mathrm{l}$ boluses containing $1 \times 10^{6}$ pathogen cells, into the mantle cavities of 16 to 20 potential hosts of each challenged mollusc species. For each challenged host species, 20 negativecontrol molluscs received $50 \mu \mathrm{l}$ placebo inoculations of the SASW inoculum diluent without pathogen cells, and 20 uninoculated individuals were processed as additional negative controls. DNAs in $100 \mu$ aliquots of each inoculum suspension were preserved in $1 \mathrm{ml}$ of absolute ethanol in a sterile tube, for use as PCR templates.

Experimental inoculations. On 4 successive days, different groups of 16 to 20 individuals from each chal- 
lenged mollusc species, received $50 \mu$ pallial cavity injections of one of the following inocula: SASW diluent (negative control), Perkinsus marinus (ATCC 50439) suspension, P. chesapeaki (ATCC PRA-65) suspension, $P$. chesapeaki (ATCC 50807) suspension. Access of the inoculating needle to the mantle cavity gill areas of experimental oysters was through a small notch made the previous day with veterinary clippers at the postero-ventral oyster valve margins opposite the gills. Clam mantle cavities were inoculated by insertion of the inoculating needle into the gill area, through their continuously exposed proximal siphon musculatures. Following inoculations, challenged mollusc groups were separately held out of water for $6 \mathrm{~h}$, humidified at 12 to $13^{\circ} \mathrm{C}$, before re-immersion in separate, covered treatment group aquaria (20 or 40 l, containing recirculating 25 ppt ASW) that were maintained at $22 \pm 1^{\circ} \mathrm{C}($ mean $\pm \mathrm{SD})$ during the experiment. Uninoculated groups of each experimental host species were separately retained in the same covered holding aquaria that were established upon their arrivals, until sacrificed for tissue and DNA samples following the last inoculation sequence.

Experiment maintenance. Depending on mortalities among experimental molluscs, treatment groups were maintained for up to $60 \mathrm{~d}$ post-inoculation (p.i.). Mollusc hosts in experimental treatment aquaria were fed daily with $100 \mu \mathrm{l}$ ind. ${ }^{-1}$ of Shellfish Diet $1800^{\mathrm{TM}}$ phytoplankton concentrate (Reed Mariculture), and a sample of phytoplankton feed cells was preserved in 10 volumes of absolute ethanol for subsequent extraction and analysis by PCR assays for the presence of Perkinsus sp. template DNA. Experimental treatment aquaria were monitored once or twice daily for removal of dead or moribund molluscs. Where possible, tissue samples from experimental hosts were preserved for both histological analyses and for PCR assays. DNAs for PCR assays were preserved by aseptic excision of mantle and gill tissues with flamed instruments, and immersion in sterile tubes containing 10 volumes of absolute ethanol. Transverse histological tissue samples were preserved for $48 \mathrm{~h}$ in Davidson's alcohol, formalin, acetic acid (AFA) fixative, before subsequent processing by standard methods for paraffin histology. Necrotic tissues from dead hosts were only preserved in ethanol for PCR assays.

Experiment termination. After 60 d, or whenever the number of surviving experimental hosts in a treatment group fell to 10 (approximate 50\% mortality), remaining treatment-group hosts were sacrificed and sampled to insure acquisition of at least 10 high-quality host tissue samples from each experimental treatment for both histological and PCR assays, and for parasite in vitro re-isolation attempts. Experimental groups that endured through $60 \mathrm{~d}$ were sacrificed and processed for tissue samples on 4 successive days, in the same order that the experimental inoculations occurred. For subsequent use of enlarged Perkinsus sp. hypnospores as in vitro re-isolate culture inocula, tissues from experimental hosts inoculated with Perkinsus spp. were incubated in RFTM that was supplemented with penicillin (200 $\mathrm{U} \mathrm{ml}^{-1}$ ), streptomycin $\left(200 \mu \mathrm{g} \mathrm{ml}^{-1}\right)$, gentamicin (200 $\mathrm{gg} \mathrm{m}^{-1}$ ), chloramphenicol (50 $\mu \mathrm{g}$ $\left.\mathrm{ml}^{-1}\right)$, and nystatin $\left(50 \mathrm{U} \mathrm{ml}^{-1}\right)$.

In vitro parasite recovery. From each experimental host mollusc that survived to treatment-group terminations, duplicate gill (clams) or mantle (oysters) tissue biopsies were inoculated into $2 \mathrm{ml}$ of RFTM in wells of duplicate 24 -well culture plates. Plates were incubated for $48 \mathrm{~h}$ at $27^{\circ} \mathrm{C}$ before tissues in wells of one replicate plate were stained with $30 \%$ (v/v) Lugol's iodine for enumeration of enlarged Perkinsus sp. hypnospores. Based on relative Perkinsus sp. cell densities estimated by RFTM assays, enlarged Perkinsus sp. hypnospores from unstained duplicate tissues of the 6 most promising individuals from each experimental treatment group were used as inocula for in vitro propagation of Perkinsus sp.

For re-isolation of Perkinsus sp., RFTM was aspirated from selected experimental tissues, and enlarged parasite hypnospores were released into suspension by trituration of tissues in $2 \mathrm{ml}$ of DME/F12-3 culture medium. Resulting inoculum suspensions were serially diluted into DME/F12-3 medium in 6 wells of a 24 -well culture plate, and incubated at $27^{\circ} \mathrm{C}$ with daily microscopic observation for Perkinsus sp. proliferation. Proliferating re-isolate cultures were expanded in culture flasks, an aliquot of cells from each re-isolate was preserved in ethanol for extraction of PCR template DNA, and viable re-isolate cells were cryopreserved in a DME/F12 freezing medium that was supplemented to $8 \%(\mathrm{v} / \mathrm{v})$ with cell culture dimethyl sulfoxide (DMSO) and $6 \%(v / v)$ FBS.

PCR assays and amplicon sequencing. Ethanol-preserved DNAs from control and challenged mollusc host tissues, Perkinsus spp. inoculum cells, phytoplankton feed cells, and Perkinsus sp. re-isolate cells were extracted using the DNAeasy Tissue Kit ${ }^{\mathrm{TM}}$ (Qiagen) following the manufacturer's protocol. DNAs isolated from Perkinsus sp. inoculum cells, the Perkinsus sp. reisolate cultures, and experimental mollusc tissues, were each used as templates in 3 separate amplifications by each of the 4 diagnostic PCR assays described below.

Genus Perkinsus-specific PCR assays (85-750-ITS [internal transcribed spacer]) were performed with methods and primers targeting rDNA sequences that are conserved among all known Perkinsus species, except $P$. qugwadi (incertae sedis) (Casas et al. 2002). PCR to test for the presence of $P$. marinus DNA was 
performed using $P$. marinus-specific primers (PmarITS), as previously described (Audemard et al. 2004). $P$. chesapeaki-specific primers (Pches-ITS) (Burreson et al. 2005) were used to test for the presence of $P$. chesapeaki DNA (forward: 5'-AAACCAGCGGTCTCTTCTTCGG-3' and reverse: 5'-CGGAATCAACCACAACACAGTCG-3'). The Pches-ITS primers were designed to target sequences of the ITS region of the rRNA gene complex that are conserved within the species $P$. chesapeaki, based on alignments of these sequences from GenBank for P. chesapeaki G117 (AF091541), ATCC PRA-65 (AY876302-AY876318), ATCC 50864 (AF440464-AF440467), ATCC 50866 (AF440468AF440471), ATCC 50807 (= P. andrewsi, AY305326), and Perkinsus sp. (AF252288). P. chesapeaki (= P. andrewsi)-specific rDNA non-transcribed spacer region primers (Pand-NTS) were used according to published protocols (Coss et al. 2001).

PCR amplifications were performed with 10 to $50 \mathrm{ng}$ of genomic template DNAs in $25 \mu \mathrm{l}$ reactions. Reagent concentrations were as follows: $20 \mathrm{mM}$ Tris- $\mathrm{HCl}$ (pH 8.4), $50 \mathrm{mM} \mathrm{KCl}, 1.5 \mathrm{mM} \mathrm{MgCl} 2,0.2 \mathrm{mM}$ each of dATP, dGTP, dCTP, dTTP, 25 pmol of each primer, 0.625 units of Taq DNA polymerase (Invitrogen), and $0.2 \mathrm{mg} \mathrm{ml}^{-1}$ of bovine serum albumin (BSA, Idaho Technology). Touchdown ${ }^{\mathrm{TM}}$ PCR amplification cycling parameters for the Pches-ITS reactions were as follows: initial DNA denaturing for $4 \mathrm{~min}$ at $94^{\circ} \mathrm{C}_{\text {; }}$ followed by 10 cycles of $30 \mathrm{~s}$ at $94^{\circ} \mathrm{C}$ and $30 \mathrm{~s}$ at $64^{\circ} \mathrm{C}$, with $\mathrm{a}-1^{\circ} \mathrm{C}$ change in annealing temperature for each cycle and $1.5 \mathrm{~min}$ extension at $72^{\circ} \mathrm{C}$; followed by 30 cycles with $30 \mathrm{~s}$ at $94^{\circ} \mathrm{C}, 30 \mathrm{~s}$ at $54^{\circ} \mathrm{C}, 1.5 \mathrm{~min}$ at $72^{\circ} \mathrm{C}$, and a final extension of $5 \mathrm{~min}$ at $72^{\circ} \mathrm{C}$. Amplification products were stained with ethidium bromide, separated on gels of $2 \%(\mathrm{w} / \mathrm{v})$ agarose in Tris-borate-EDTA buffer (1× TBE), and visualized under UV light.

To confirm Perkinsus spp. identities and assay specificities, amplification products from 2 to 5 experimental host tissue DNAs representing each treatment regime were sequenced by simultaneous bi-directional cycle- sequencing as previously described (Reece \& Stokes 2003). DNAs were extracted from the $P$. chesapeaki in vitro cultures that were re-isolated from tissues of challenged hosts, and PCR amplification products were sequenced to confirm isolate identities.

Histological assays. Histological sections of paraffinembedded experimental tissue samples were cut at 5 to $6 \mu \mathrm{m}$ for collection and drying onto poly-L-lysinecoated microscope slides. Sections were de-waxed, rehydrated, and stained with Mayer's hematoxylin and eosin (H\&E) for histopathological analyses.

\section{RESULTS}

The PCR primers specific for the genus Perkinsus (85-750-ITS) yielded approximate $750 \mathrm{bp}$ amplicons, and primers specific for P. marinus (Pmar-ITS) and $P$. chesapeaki (Pches-ITS) amplified products of approximately 509 and 554 bp, respectively, from DNA templates of axenic isolate inocula, and from tissue DNAs of oysters and clams experimentally challenged with the $P$. marinus inoculum or the $2 P$. chesapeaki inocula. These PCR products were confidently differentiated and identified by size, following electrophoretic separation on standard agarose gels. Template DNA from the commercial phytoplankton concentrate used to feed experimental molluscs was negative by all PCR assays, as were tissue DNAs from experimental molluscs that received no inoculation, or that received the negative-control SASW diluent inoculum (Table 1).

Tissue DNAs from Perkinsus sp.-inoculated experimental host molluscs were positive at variable incidences, and only by PCR assays specific for inoculated pathogen species. Based on pathogen-species PCR assay results, all 3 experimental mollusc host species acquired infections by all 3 Perkinsus sp. challenge isolates at 33 to $100 \%$ incidences (Table 1). The highest experimental infection incidences (83 to $100 \%$ ) consistently occurred in experimental hosts

Table 1. Crassostrea virginica, Mya arenaria and Macoma balthica. Proportions (\%) of experimental mollusc host treatment groups in which species-specific rDNA internal transcribed spacer (ITS)-region PCR assays detected experimental parasite species' DNA at host death or treatment termination. SASW: sterile artificial seawater; Pmar-ITS: Perkinsus marinus-specific assay; Pches-ITS: P. chesapeaki-specific assay

\begin{tabular}{|c|c|c|c|c|c|c|}
\hline \multirow{3}{*}{$\begin{array}{l}\text { Treatment inocula } \\
\qquad \text { Host: } \\
\text { PCR assay: }\end{array}$} & \multicolumn{6}{|c|}{ \% infected $(\mathrm{n})$} \\
\hline & \multicolumn{2}{|c|}{ C. virginica } & \multicolumn{2}{|c|}{$\begin{array}{c}\% \text { infected }(\mathrm{n}) \\
M . \text { arenaria }\end{array}$} & \multicolumn{2}{|c|}{ M. balthica } \\
\hline & Pmar-ITS & Pches-ITS & Pmar-ITS & Pches-ITS & Pmar-ITS & Pches-ITS \\
\hline Uninoculated & $0(0 / 20)$ & $0(0 / 20)$ & $0(0 / 20)$ & $0(0 / 20)$ & $0(0 / 20)$ & $0(0 / 20)$ \\
\hline SASW & $0(0 / 20)$ & $0(0 / 20)$ & $0(0 / 20)$ & $0(0 / 20)$ & $0(0 / 20)$ & $0(0 / 20)$ \\
\hline P. marinus ATCC 50439 & $45(9 / 20)$ & $0(0 / 20)$ & $30(6 / 20)$ & $0(0 / 20)$ & $83(15 / 20)$ & $0(0 / 18)$ \\
\hline P. chesapeaki ATCC PRA-65 & $0(0 / 20)$ & $100(20 / 20)$ & $0(0 / 18)$ & $33(6 / 18)$ & $0(0 / 20)$ & $70(14 / 20)$ \\
\hline P. chesapeaki ATCC 50807 & $0(0 / 20)$ & $90(18 / 20)$ & $0(0 / 16)$ & $38(6 / 16)$ & $0(0 / 20)$ & $45(9 / 20)$ \\
\hline
\end{tabular}


that were not the original, cognate source-hosts for experimental Perkinsus spp. challenge isolates. Thus, 90 and $100 \%$ of oyster host treatments were infected when challenged with the $2 P$. chesapeaki isolates, ATCC 50807 and PRA-65, respectively, that were originally isolated from clams. Likewise, $83 \%$ of experimental Macoma balthica clams were infected when challenged with the P. marinus isolate (ATCC 50439) from an oyster.

Infection incidences estimated by results of PCR assays on DNAs from challenged molluscs were consistent between the genus-Perkinsus 85-750-ITS assay and both of the species-specific Pmar-ITS and PchesITS PCR assays. In contrast, the Pand-NTS assay (Coss et al. 2001) detected only 17 to $56 \%$ of the infections that were detected by either the 85-750-ITS or PchesITS assays among experimental hosts challenged with either of the $2 P$. chesapeaki isolates (Table 2). Sequence analyses of amplification products from the species-specific Pmar-ITS and Pches-ITS PCR assays confirmed the identities of all detected Perkinsus spp. to be the same as those of the in vitro isolates used to challenge specific host groups.

The same Perkinsus sp. isolates that were used to challenge experimental hosts were re-isolated and propagated in vitro from tissues of all 3 host species following termination of some, but not all, inoculated treatments (Table 3). Viable, histozoic Perkinsus sp. hypnospores enlarged, and were universally detected at 10 to $89 \%$ incidences, following RFTM incubations of tissues from Perkinsus sp.-inoculated experimental host treatments. Perkinsus spp. challenge isolates were re-isolated in vitro from tissues of challenged hosts in 5 of 9 inoculated treatment groups (Table 3),

Table 2. Crassostrea virginica, Mya arenaria and Macoma balthica. Perkinsus spp. infections in experimental host tissues detected by each of 4 different PCR rDNA assays. ITS: internal transcribed spacer; Pmar-ITS: Perkinsus marinus-specific assay; Pches-ITS: P. chesapeaki-specific assay; Pand-NTS; $P$. chesapeaki (= P. andrewsi)-specific non-transcribed spacer assay; SASW: sterile artificial seawater

\begin{tabular}{|c|c|c|c|c|c|}
\hline \multirow{2}{*}{ Host species } & \multirow{2}{*}{ Inoculum } & \multicolumn{4}{|c|}{$\%$ infected by PCR assays - } \\
\hline & & $\begin{array}{c}\text { Perkinsus spp. } \\
\text { 85-750-ITS }\end{array}$ & $\begin{array}{l}\text { P. marinus } \\
\text { Pmar-ITS }\end{array}$ & $\begin{array}{l}\text { P. chesapeaki } \\
\text { Pches-ITS }\end{array}$ & $\begin{array}{l}\text { P. chesapeaki } \\
\text { Pand-NTS }\end{array}$ \\
\hline All tested & Uninoculated & 0 & 0 & 0 & 0 \\
\hline All tested & SASW & 0 & 0 & 0 & 0 \\
\hline C. virginica & P. marinus ATCC 50439 & 45 & 45 & 0 & 0 \\
\hline M. arenaria & & 40 & 30 & 0 & 0 \\
\hline M. balthica & & 83 & 83 & 0 & 0 \\
\hline C. virginica & P. chesapeaki ATCC PRA-65 & 95 & 0 & 100 & 40 \\
\hline M. arenaria & & 22 & 0 & 33 & 6 \\
\hline M. balthica & & 65 & 0 & 70 & 15 \\
\hline C. virginica & P. chesapeaki ATCC 50807 & 90 & 0 & 90 & 50 \\
\hline M. arenaria & & 31 & 0 & 38 & 6 \\
\hline M. balthica & & 45 & 0 & 45 & 10 \\
\hline
\end{tabular}

Table 3. Crassostrea virginica, Mya arenaria and Macoma balthica. In vitro re-isolation and propagation of experimental Perkinsus sp. challenge isolates from infected experimental mollusc host tissues. RFTM: Ray's fluid thioglycollate medium; ITS: internal transcribed spacer; SASW: sterile artificial seawater; nd: not done; na: not applicable

\begin{tabular}{|c|c|c|c|c|c|}
\hline Host species & Inoculum & $\begin{array}{c}\text { Infected by } \\
\text { RFTM assay } \\
\%(n)\end{array}$ & $\begin{array}{c}\text { Re-isolation } \\
\text { frequency } \\
\%(n)\end{array}$ & $\begin{array}{c}\text { Re-isolate } \mathrm{r} \\
\text { P. marinus } \\
\%\end{array}$ & $\begin{array}{l}\text { A-ITS identities } \\
\text { P. chesapeaki } \\
\%\end{array}$ \\
\hline All tested & SASW & $0(0 / 10)$ & nd & na & na \\
\hline C. virginica & \multirow[t]{3}{*}{ P. marinus ATCC 50439} & $50(5 / 10)$ & $0(0 / 6)$ & na & na \\
\hline M. arenaria & & $70(7 / 10)$ & $0(0 / 6)$ & na & na \\
\hline M. balthica & & $89(8 / 9)$ & $0(0 / 6)$ & na & na \\
\hline C. virginica & \multirow[t]{3}{*}{ P. chesapeaki ATCC PRA-65 } & $80(8 / 10)$ & $33(2 / 6)$ & 0 & 100 \\
\hline M. arenaria & & $60(6 / 10)$ & $33(2 / 6)$ & 0 & 100 \\
\hline M. balthica & & $50(5 / 10)$ & $17(1 / 6)$ & 0 & 100 \\
\hline C. virginica & \multirow[t]{3}{*}{ P. chesapeaki ATCC 50807} & $40(4 / 10)$ & $83(5 / 6)$ & 0 & 100 \\
\hline M. arenaria & & $10(1 / 10)$ & $17(1 / 6)$ & 0 & 100 \\
\hline M. balthica & & $40(4 / 10)$ & $0(0 / 6)$ & na & na \\
\hline
\end{tabular}


confirming the presence of viable cells of Perkinsus sp. challenge isolates in experimental host tissues sampled at 9 to $44 \mathrm{~d}$ p.i. Sequence analyses of PCR products amplified from DNAs of all 11 re-isolates confirmed their identities with respective $P$. chesapeaki treatment inocula.

The Perkinsus marinus experimental isolate (ATCC 50439) was not re-isolated in vitro from any of the challenged host species, due in part to rapid overgrowth of all $P$. marinus re-isolation cultures by vigorous thraustochytrid contaminants. The $P$. chesapeaki neohapantotype isolate from a Mya arenaria clam (ATCC PRA-65) was re-isolated from members of each experimentally challenged mollusc species. The $P$. chesapeaki experimental isolate that originated from a Macoma balthica clam (ATCC 50807) was frequently re-isolated from tissues of challenged oysters (5 of 6), and from tissues of 1 of $6 \mathrm{M}$. arenaria clams, but was not re-isolated from tissues of any $M$. balthica experimental clams.

Lesions containing proliferating Perkinsus sp. cells were detected at variable frequencies ( 7 to $55 \%$ ) in histological sections of available tissues from all challenged, experimental mollusc host groups, providing in situ confirmation of active infections in all groups of experimentally challenged hosts (Table 4). Detection frequencies of histological assays fell consistently and often dramatically below those of both RFTM (Table 4) and PCR assays (Table 2) for all experimental treatments. Among experimental host groups challenged with each of the 3 experimental Perkinsus sp. isolates, histological lesions were consistently detected at highest frequencies among challenged Macoma balthica clams, at lowest frequencies among challenged Мya arenaria clams, and at intermediate frequencies among challenged Crassostrea virginica oysters.
Among hosts challenged with different experimental Perkinsus sp. isolates, $P$. marinus lesions were found in both epithelial and connective tissues, while experimental lesions from either of the $P$. chesapeaki challenge isolates were found almost exclusively in host connective tissues (Table 4).

Experimental Perkinsus marinus (ATCC 50439) lesions were found in host mantle and intestinal epithelia among challenged Crassostrea virginica oysters, and lesions from both $P$. chesapeaki challenge isolates (ATCC PRA-65, ATCC 50807) were found in challenged $C$. virginica mantle (Figs. 1 \& 2), gill, and visceral connective tissues, but rarely in oyster digestive epithelia (Table 4). In experimental Mya arenaria clam hosts, $P$. marinus lesions were found in gill epithelia, and in connective tissues of mantle (Fig. 3), gill, kidney, and viscera. In experimental Macoma balthica clam hosts, $P$. marinus lesions were found in gill epithelial and connective tissues (Fig. 4), mantle epithelial and connective tissues, and in visceral, kidney, and nervous connective tissues. Among both challenged experimental clam hosts, $P$. chesapeaki lesions were found in connective tissues of gills, mantle, viscera, gonad, kidney, and adductor muscle, as previously documented (Burreson et al. 2005).

Cumulative mortalities among inoculated experimental hosts varied with general consistency between challenged host species, and varied with less consistency between host groups challenged with different Perkinsus sp. isolates (Fig. 5). Among challenged host species, Macoma balthica clams generally showed the highest mortality rates, and Perkinsus sp.-inoculated M. balthica treatments were all terminated upon reaching their $50 \%$ mortality threshold at 15 to $17 \mathrm{~d}$ p.i. In contrast, the SASW placebo-inoculated $M$. balthica treatment endured to termination at $26 \mathrm{~d}$ p.i. Cras-

Table 4. Crassostrea virginica, Mya arenaria and Macoma balthica. Frequency and tissue locations of Perkinsus sp. lesions detected by histological assays of experimental mollusc hosts. RFTM: Ray's fluid thioglycollate medium

\begin{tabular}{|c|c|c|c|c|}
\hline Host species & Inoculum & $\begin{array}{c}\text { Positive } \\
\text { RFTM assay } \\
\text { frequencies } \\
\%(n)\end{array}$ & $\begin{array}{l}\text { Histological } \\
\text { lesion } \\
\text { frequencies } \\
\%(n)\end{array}$ & Histological lesion sites \\
\hline C. virginica & P. marinus ATCC 50439 & $50(5 / 10)$ & $15(3 / 20)$ & Mantle and intestine epithelia \\
\hline M. arenaria & & $70(7 / 10)$ & $7(1 / 15)$ & Gill epithelium \\
\hline M. balthica & & $89(8 / 9)$ & $55(6 / 11)$ & $\begin{array}{l}\text { Mantle, gill, visceral, kidney, nerve } \\
\text { connective tissues; gill epithelium }\end{array}$ \\
\hline C. virginica & P. chesapeaki ATCC PRA-65 & $80(8 / 10)$ & $11(2 / 18)$ & Mantle, visceral, vascular connective tissues \\
\hline M. arenaria & & $60(6 / 10)$ & $6(1 / 16)$ & Gill connective tissue \\
\hline M. balthica & & $50(5 / 10)$ & $50(6 / 12)$ & Mantle, gill, visceral, kidney connective tissues \\
\hline C. virginica & P. chesapeaki ATCC 50807 & $40(4 / 10)$ & $18(3 / 17)$ & Mantle connective tissue; intestine epithelium \\
\hline M. arenaria & & $10(1 / 10)$ & $8(1 / 12)$ & Gill connective tissue \\
\hline M. balthica & & $40(4 / 10)$ & $40(6 / 15)$ & Mantle, gonad, adductor muscle connective tissues \\
\hline
\end{tabular}



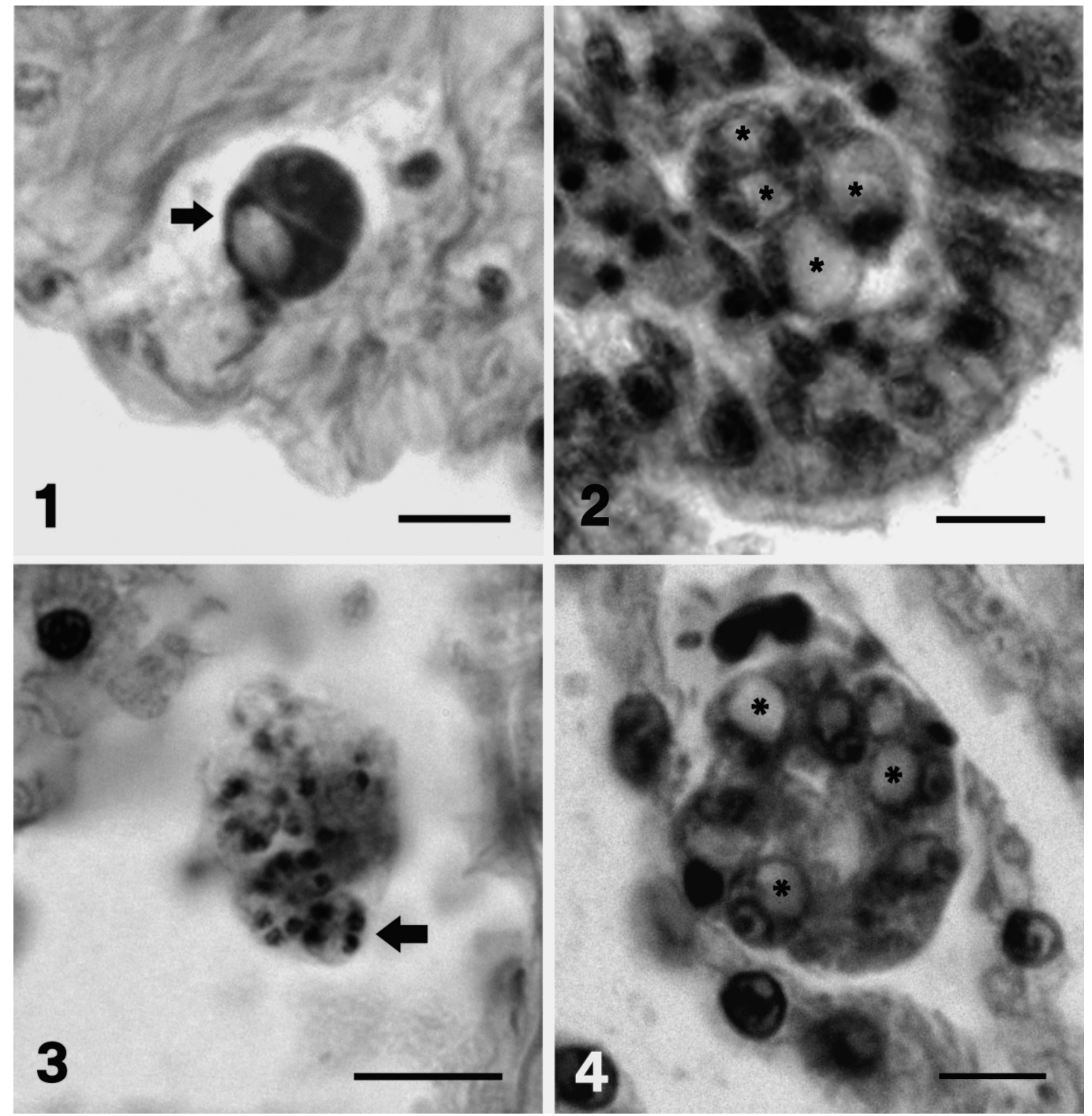

Figs. 1 to 4. Crassostrea virginica, Mya arenaria and Macoma balthica. Histological lesions in experimental oysters and clams challenged with 3 Perkinsus sp. in vitro isolates of 2 species. All scale bars $=10 \mu \mathrm{m}$. Fig. 1. C. virginica pallial mantle epithelium lesion containing a pair of dividing $P$. chesapeaki (ATCC PRA-65) trophozoites (arrow) that show an eccentric vacuole (lower) and a nucleus with prominent nucleolus (upper). Fig. 2. Pallial mantle epithelium lesion in $C$. virginica containing a group of proliferating P. chesapeaki (ATCC 50807) cells (*). Fig. 3. M. arenaria mantle vasculature containing a large aggregate of small, vacuolated $P$. marinus cells, including a dividing 4-cell schizont (arrow). Fig. 4. M. balthica gill epithelium lesion containinga colony of P. marinus trophozoites $(*)$

sostrea virginica oysters generally experienced the lowest mortality rates among pathogen-challenged experimental hosts, with Perkinsus sp.-inoculated treatments terminated at 11 to $59 \mathrm{~d}$ p.i. Mya arenaria clams showed generally intermediate mortality rates, with Perkinsus sp.-inoculated treatments terminated at 9 to $44 \mathrm{~d}$ p.i. The $C$. virginica treatment group challenge with its cognate $P$. marinus pathogen isolate (ATCC 50439) showed the lowest overall mortality rate among oyster treatment groups, while among both clam species, the lowest mortality rates were found among SASW placebo-inoculated treatments.

\section{DISCUSSION}

The results reported here demonstrate that each of the 3 species of experimental mollusc hosts that we challenged with mantle cavity inoculations of cultured pathogen cells were infected by both Perkinsus marinus and P. chesapeaki. Conspecifics of each Chesapeake Bay mollusc host from which the tested Perkinsus spp. isolates originated became infected, as did 2 other mollusc species that are sympatric with the origin-host in many Chesapeake Bay habitats. These experimental results are consistent with the broad host 
specificities inferred from results of PCR assays for $P$. marinus and $P$. chesapeaki that have previously been reported from some of the same species of wild Chesapeake Bay clams and oyster (Kotob et al. 1999, Coss et al. 2001). These previous PCR results and our current experimental results both remain inconsistent,
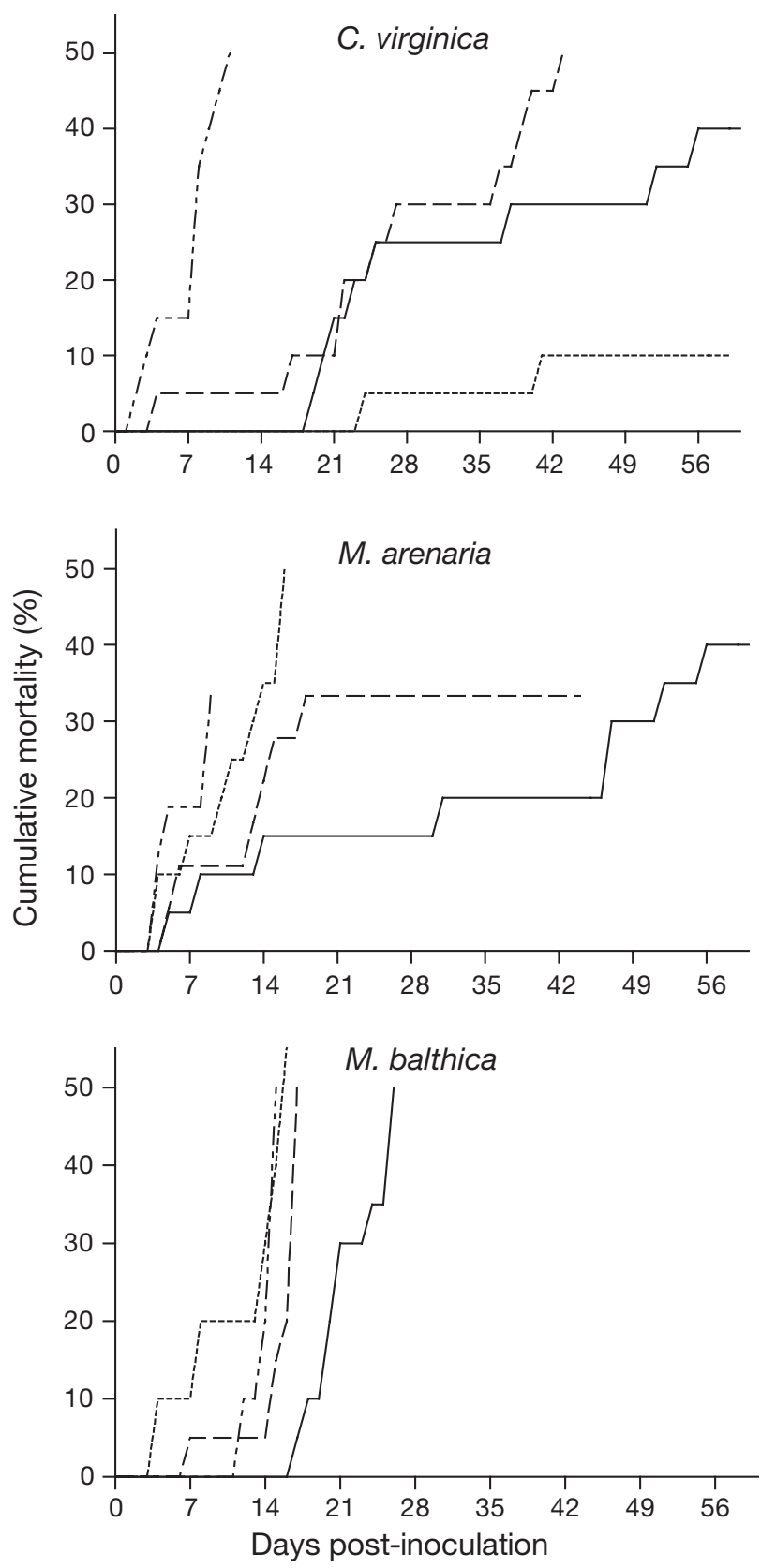

Fig. 5. Crassostrea virginica, Mya arenaria and Macoma balthica. Cumulative mortalities among 3 experimental mollusc host species challenged with different Perkinsus sp. isolates, or with sterile artificial seawater (SASW) diluent. Inoculum treatment series include SASW placebo (control) (-), P. marinus ATCC 50439 (…..), P. chesapeaki ATCC PRA-65 (---), and P. chesapeaki ATCC $50807\left(-\cdot{ }^{-\cdot-)}\right.$ however, with the narrow host specificities inferred by the extensive and exclusive historical propagation only of $P$. marinus in vitro isolates from Chesapeake Bay oysters, and of the nearly exclusive propagation of P. chesapeaki isolates from diverse Chesapeake Bay clam species (La Peyre et al. 2006).

Our principal methods for detecting Perkinsus sp. infections in experimental mollusc tissues were species-specific PCR assays. However, such assays can also detect non-infecting parasite cells, and DNAs that may persist in experimental systems. Potential confounding PCR template sources include residual cellfree DNAs from experimental inocula, or DNAs from both live and dead, but non-infecting, parasite cells that may passively associate with experimental host tissues. The persistence of only inoculum-speciesspecific PCR results from assays on DNAs extracted from experimental host tissues collected throughout the duration of our experiment confirm effective prevention of experimental treatment cross-contaminations and suggest that these results reflect active Perkinsus sp. infections in experimental host tissues.

Despite a typically low probability for detection of in situ lesions in random histological sections from recently infected experimental hosts harboring potential light infections, we consistently documented lesions containing proliferating Perkinsus sp. cells in at least some histological sections of experimental host tissues from every treatment group that we challenged with Perkinsus sp. isolate cells. Those histological results confirm active infections by all of our experimental Perkinsus sp. isolates, and provide compelling evidence of subsequent pathogen proliferation in infected host tissues. Both PCR and histological results were further substantiated by positive RFTM assays of experimental host tissues, and by our consistent, although not universal, re-isolation and propagation of Perkinsus sp. inoculum cultures from such tissues.

Due to uncertainty on the number of Perkinsus spp. extant in Chesapeake Bay at the time of our experiment, parasite isolates originally described as $P$. chesapeaki and $P$. andrewsi were both used in our challenge experiments. These 2 isolates are now known to be synonymous representatives of $P$. chesapeaki (Burreson et al. 2005), and our similar results following experimental challenges of Mya arenaria and Macoma balthica clams with both $P$. chesapeaki isolates are consistent with the strong genetic and morphological evidence that those isolates are members of the same parasite species.

The generally high mortality rates among our experimental clam host species may reflect negative consequences of our sediment-free experimental system for host clams that normally live buried, supported, and compressed in benthic or intertidal substrates. Such 
negative effects were probably compounded for deposit-feeding Macoma balthica host clams, by our deposit-free experimental design. However, Perkinsus sp.-inoculated treatments for both clam hosts consistently showed higher mortality rates than placebo-inoculated controls, reflecting probable differential pathogenic effects from experimental infections. Since hosts of different sizes were inoculated with the same total dose of Perkinsus sp. isolate cells, smaller $M$. balthica clams may have received higher effective challenge doses, if infectivity is modulated by the density of infectious pathogen cells impinging on smaller tissue surface areas available for colonization in smaller hosts.

Similar differential mortality trends among most Perkinsus sp.-challenged oyster treatments were apparently contradicted by the lowest overall mortality rate that occurred among oysters challenged with the $P$. marinus isolate of oyster origin. Whether that low mortality rate reflects relative specific resistance to $P$. marinus pathology by oysters in general, or by the specific oysters used in our experiment, is speculative. Arguing for random coincidence as the basis for that low experimental mortality is the fact that our experimental Crassostrea virginica hosts were propagated from a brood line that has not been exposed to P. marinus for at least $90 \mathrm{yr}$ and has not been actively selected for dermo disease resistance during that time. In all cases, however, the highest mortality rates in our experimental treatments consistently occurred in naïve mollusc host groups challenged with a Perkinsus sp. isolate from a different host species.

Under the controlled conditions of our experimental design, all 3 challenged hosts were susceptible to infections by all 3 Perkinsus sp. isolates used to challenge them. Whether, and to what extent, $P$. marinus and $P$. chesapeaki naturally cross- or co-infect the same sympatric, wild mollusc hosts in Chesapeake Bay waters is the subject of a separate current investigation to specifically evaluate those possibilities.

Acknowledgements. The reported research was funded in part by NOAA Sea Grant Oyster Disease Research Program award NA16RG1697 (VA-OD 0104). Interpretations of results are those of the authors. Essential and expert contributions were made by K. L. Hudson (VIMS) for both PCR assays and DNA sequencing, by R. Crockett (VIMS) for histopathology, by J. M. Blazek (MDDNR) for histological preparations, and by J. Chapman, Jr. (Newport, OR) and D. Robertson (Taylor Shellfish, Inc.) for timely provisions of USA Pacific coast clams and oysters. This is VIMS contribution 2820.

\section{LITERATURE CITED}

Andrews JD (1953) Notes on fungus parasites of bivalve mollusks in Chesapeake Bay. Proc Natl Shellfish Assoc 45: $157-163$
Andrews JD, Hewatt WG (1957) Oyster mortality studies in Virginia. II. The fungus disease caused by Dermocystidium marinum in oysters of Chesapeake Bay. Ecol Monogr $27: 1-25$

Audemard C, Reece KS, Burreson EM (2004) Real-time PCR for detection and quantification of the protistan parasite Perkinsus marinus in environmental waters. Appl Environ Microbiol 70:6611-6618

Burreson EM, Reece KS, Dungan CF (2005) Molecular, morphological, and experimental evidence support synonymy of Perkinsus chesapeaki and Perkinsus andrewsi. J Eukaryot Microbiol 52:258-270

Casas SM, Villalba A, Reece KS (2002) Study of perkinsiosis in the carpet shell clam Tapes decussatus in Galicia (NW Spain). I. Identification of the aetiological agent and in vitro modulation of zoosporulation by temperature and salinity. Dis Aquat Org 50:51-65

Coss CA, Robledo JAF, Ruiz GM, Vasta GR (2001) Description of Perkinsus andrewsi n. sp. isolated from the Baltic clam (Macoma balthica) by characterization of the ribosomal RNA locus, and development of a species-specific PCR-based diagnostic assay. J Eukaryot Microbiol 48: $52-61$

Dungan CF, Hamilton RM (1995) Use of a tetrazolium-based cell proliferation assay to measure effects of in vitro conditions on Perkinsus marinus (Apicomplexa) proliferation. J Eukaryot Microbiol 42:379-388

Dungan CF, Hamilton RM, Hudson KL, McCollough CB, Reece KS (2002) Two epizootic diseases in Chesapeake Bay commercial clams, Mya arenaria and Tagelus plebeius. Dis Aquat Org 50:67-78

Kotob SI, McLaughlin SM, van Berkum P, Faisal M (1999) Characterization of two Perkinsus spp. from the softshell clam, Mya arenaria, using the small subunit ribosomal RNA gene. J Eukaryot Microbiol 46:439-444

La Peyre M, Casas S, La Peyre J (2006) Salinity effects on viability, metabolic activity, and cellular proliferation of three Perkinsus species. Dis Aquat Org 71:59-74

Mackin JG, Owen HM, Collier A (1950) Preliminary note on the occurrence of a new protistan parasite, Dermocystidium marinum n. sp. in Crassostrea virginica (Gmelin). Science 111:328-229

McLaughlin SM, Faisal M (1998) In vitro propagation of two Perkinsus species from the softshell clam Mya arenaria. Parasite 5:341-348

McLaughlin SM, Faisal M (2000) Prevalence of Perkinsus spp. in Chesapeake Bay soft-shell clams, Mya arenaria Linneaeus, 1758 during 1990-1998. J Shellfish Res 19: 349-352

McLaughlin SM, Tall BD, Shaheen A, El Sayed EE, Faisal M (2000) Zoosporulation of a new Perkinsus species isolated from the gills of the softshell clam Mya arenaria. Parasite 7:115-122

Moss JA, Burreson EM, Reece KS (2006) Advanced Perkinsus marinus infections in Crassostrea ariakensis maintained under laboratory conditions. J Shellfish Res 25:65-72

Ray SM (1952) A culture technique for the diagnosis of infections by Dermocystidium marinum Mackin, Owen, and Collier in oysters. Science 116:360-361

Ray SM, Chandler AC (1955) Dermocystidium marinum, a parasite of oysters. Exp Parasitol 4:172-200

Reece KS, Stokes NA (2003) Molecular analysis of a haplosporidian parasite from cultured New Zealand abalone Haliotis iris. Dis Aquat Org 53:61-66

Valiulis GA, Mackin JG (1969) Formation of sporangia and zoospores by Labyrinthomyxa sp. parasitic in the clam Macoma balthica. J Invertebr Pathol 14:268-270 